


\title{
PATH ANALYSIS OF RECORDING SYSTEM INNOVATION FACTORS AFFECTING ADOPTION OF GOAT FARMERS
}

\author{
S. Okkyla, S. Dwijatmiko and E. Kurnianto \\ Faculty of Animal and Agricultural Sciences, Diponegoro University, \\ Tembalang Campus, Semarang 50275, Central Java - Indonesia \\ Corresponding E-mail:septikaokkyla033@yahoo.co.id
}

Received January 04, 2014; Accepted Fabruary 27, 2014

\begin{abstract}
ABSTRAK
Penelitian ini bertujuan untuk mengevaluasi analisis jalur faktor-faktor inovasi sistem recording yang mempengaruhi adopsi pada peternak kambing. Penelitian dilaksanakan pada bulan JanuariFebruari 2014 di Kecamatan Pringapus Kabupaten Semarang dengan metode survei. Lokasi penelitian ditentukan dengan metode purposive sampling dan jumlah responden ditentukan dengan metode quota sampling. Responden yang terpilih secara acak berjumlah 146 orang. Data yang diperoleh dianalisis secara deskriptif kuantitatif menggunakan analisis jalur dengan bantuan Statistical Package for the Social Science (SPSS) 16. Variabel bebas pada penelitian ini adalah faktor internal, motivasi, sifat inovasi dan sumber informasi sedangkan variabel tidak bebas adalah adopsi. Hasil perhitungan linear regression menunjukan faktor internal tidak signifikan terhadap adopsi sehingga pada analisis jalur perlu dilakukannya metode trimming. Berdasarkan hasil analisis jalur diketahui total pengaruh variabel motivasi, sifat inovasi dan sumber informasi terhadap adopsi masing-masing 0,168;0,720 dan 0,091. Variabel sifat inovasi memberikan pengaruh total paling besar terhadap adopsi, sehingga dapat disimpulkan dengan meningkatkan sifat inovasi responden melalui motivasi dan sumber informasi akan secara signifikan meningkatkan adopsi sistem recording pada peternak kambing
\end{abstract}

Kata kunci : faktor inovasi, adopsi, recording, analisis jalur

\begin{abstract}
The objective of this study was to evaluate the path analysis of recording system innovation factors affecting adoption of goat farmers. This study was conducted from January to February 2014 in Pringapus District, Semarang Regency by using survey method. For determining the location, this study used purposive sampling method. The amount of respondents were determined by quota sampling method. Total respondents randomly chosed were 146 farmers. The data were descriptively and quantitatively analyzed by using path analysis of statistical package for the social science (SPSS) 16. Independent variables in this study were internal factor, motivation, innovation characteristics, information source, and dependent variable was adoption. Analysis of linear regression showed that there was no significant effect of internal factor on adoption, so that it was important to use the trimming method in path analysis. The result of path analysis showed that the influence of motivation, innovation characteristics and information source on adoption were $0.168 ; 0.720$ and 0.09 , respectively. Innovation characteristics were the greatest effect on adoption. In conclusion, by improving innovation characteristics of respondent through motivation and information source may significantly increase the adoption of recording system in goat farmers.
\end{abstract}

Keywords: innovation characteristic, adoption, recording, path analysis

\section{INTRODUCTION}

The success of goat farm business depends on breeding, feeding and management. An efficient proper management will produce high quality product. Production management was begun from planning, implementation, evaluation should be periodically recorded by recording system. In this case, recording system is an absolute requirement that should be conducted by goat farmer.

Recording system is conducted to record the 
history of livestock and the farm management by the farmer (Kosgey et al., 2011). Recording system is a beneficial system that should be authorized by the farmer but only few of them decide to accept that innovation. Government has already encouraged the farmers to apply recording system through socialization, in fact most of them could not adopt it. An individual farmer will receive the innovation through several steps, those are awareness, interest, judgment, implementation and adoption. The process of adopting innovation related to the acceleration of the farmer whether to accept or reject it. The acceleration of adoption is affected by innovation factors such as internal factor, motivation, innovation characteristics and information sources (Harinta, 2010).

Based on the reasons above, this study was conducted to observe and determine innovation factor of recording system affecting adoption in goat farmers through path analysis.

\section{MATERIALS AND METHODS}

\section{Research Approach}

The study was conducted from January to February 2014. The location of the study was determined by applying purposive sampling method. Location selected was Pringapus District, Semarang Regency, Central Java Province. Total respondents of the study were 146 farmers, originated from 12 farmers group spreading over 3 villages, namely Pringapus Village, Klepu and Wanarejo.

\section{Sampling Method}

Determination of respondent amount was conducted by quota sampling method. Sample collection was deliberately taken by considering the total amount of farmer from each farmer group member in Pringapus District, Semarang Regency. Farmer groups were divided into three groups, those were 80 respondents of big group, 60 respondents of medium group and 6 respondents of small group. The total number of respondent was 146 farmers.

\section{Data Collection Method}

Survey method was used in this study. The primary data were obtained through interview and observation by using questionnaire, then calculated it with scoring. Secondary data were obtained through documentary study such as report, data record and important files originated from several institutions and literatures.

\section{Regression Coefficient Test}

Regression coefficient test was used to analyze the effect of variable simultaneously and partially (individually) and both of directly and indirectly effect between independent and dependent variables. The formula was:

$\mathrm{Y}=\mathrm{b}_{0}+\mathrm{b}_{1} \mathrm{X}_{1}+\mathrm{b}_{2} \mathrm{X}_{2}+\mathrm{b}_{3} \mathrm{X}_{3}+\mathrm{b}_{4} \mathrm{X}_{4}+\mathrm{e}$

Where:

Y: Adoption

$\mathrm{X}_{1 \text { : Internal factor }}$

$\mathrm{X}_{2 \text { : }}$ Motivation

$\mathrm{X}_{3 \text { : Innovation characteristics }}$

$\mathrm{X}_{4 \text { : }}$ Information sources

$\mathrm{b}_{0}$ : Constant

E : error

\section{Path Analysis}

Path analysis is a method to analyze the causal correlation which occurs in multiple regression, if the independent variables affect dependent variable both directly and indirectly (Sarwono, 2007). There are two main analysis methods within path analysis, those are decomposition and trimming method. Decomposition method is utilized to establish cause model by inserting all of observed variables. Trimming method is utilized to repair model structure of path analysis by eliminating non significant independent variables and recalculating it (Rofin, 2009). The description of path analysis is presented in Figure 1 and the formulas of path analysis are presented in equation 2 to 6 .

- Structural equation:

$\mathrm{Y}=\rho \mathrm{YX} 1 \mathrm{X}_{1}+\rho \mathrm{YX} 2 \mathrm{X}_{2}+\mathrm{rYX} 3 \mathrm{X}_{3}+\rho \mathrm{YX} 4 \mathrm{X}_{4}$ $+\varepsilon \ldots(2)$

- Residual coefficient path:

$\rho \mathrm{Y} \varepsilon=\sqrt{1-\mathrm{R}^{2}}$

- Direct effect of $\mathrm{X}_{\mathrm{i}}$ on $\mathrm{Y}=\left(\rho \mathrm{YX}_{i}\right)^{2}$

- Indirect effect of $X_{i}$ on $Y$ through

- Indirect effect of $\mathrm{X}_{\mathrm{i}}$ on $\mathrm{Y}$ through the correlative relationship of $\mathrm{X}_{\mathrm{j}}=\rho \mathrm{YX}_{i} \cdot \mathrm{r}_{\mathrm{x} i \mathrm{x} j} . \mathrm{PYX}_{j} \ldots \ldots . .$.

- Total effect of $\mathrm{X}_{i}$ on $\mathrm{Y}$ :

$\rho \mathrm{Y}_{\text {total }}=\left(\rho \mathrm{YX}_{i}\right)^{2}+\mathrm{S}\left(\rho \mathrm{YX}_{i} \times \mathrm{r}_{\mathrm{xixj}} \mathrm{X} \rho \mathrm{YX} \mathrm{X}_{j}\right) \ldots$

Where : $i=1,2,3,4 ; j=1,2,3,4$ and $(i \neq j)$

Independent variables in this study were internal factor $\left(\mathrm{X}_{1}\right)$, motivation $\left(\mathrm{X}_{2}\right)$, innovation characteristics $\left(\mathrm{X}_{3}\right)$ and information source $\left(\mathrm{X}_{4}\right)$, meanwhile the dependent variable was adoption (Y). Path analysis was aimed to observe the direct 


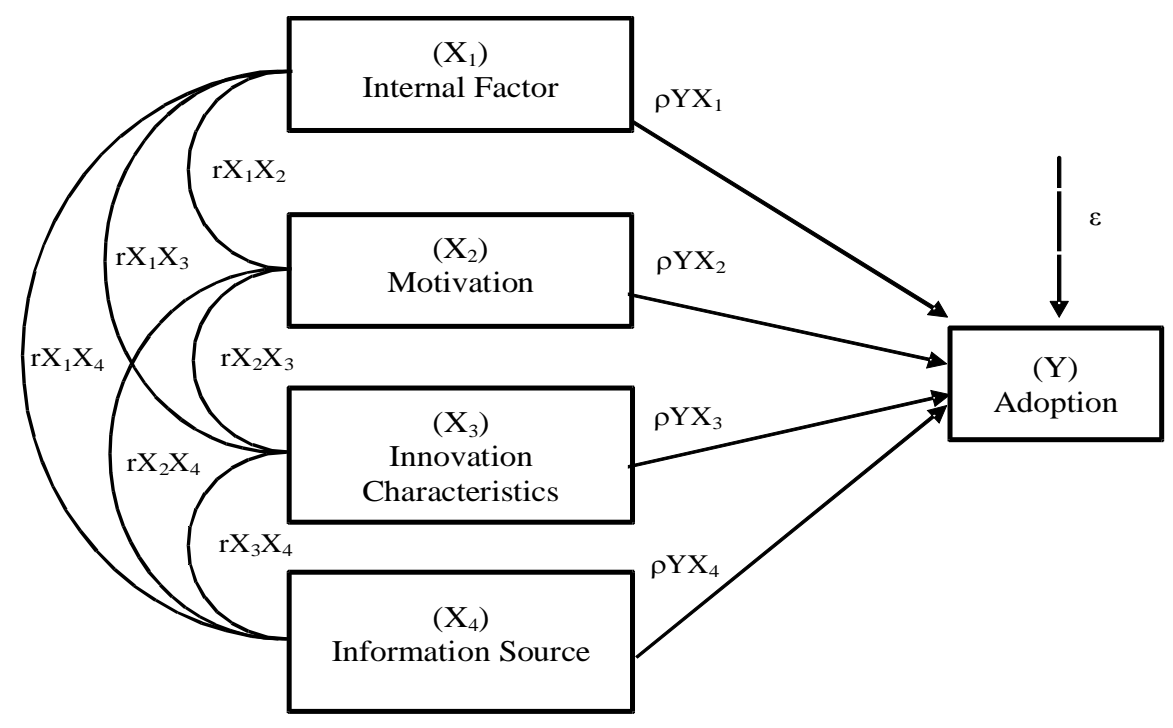

Figure 1. Path Analysis

and indirect effects of internal factor, motivation, innovation characteristics and information source on adoption. Regression and Pearson correlation were used in path analysis test by using SPSS 16 .

\section{RESULTS AND DISCUSSION}

\section{Farmer Identity}

Identity of farmer consisted of age, education background, farming experience, total number of livestock ownership and primary livelihood. The data showed that $91.78 \%$ of goat farmers were in productive age category that was between 15-55 years old. The productive age of goat farmers have strong endurance to do their activities. Accordingf characteristics influencing biological and physiological function of individual.

Approximately $45.21 \%$ of farmers graduated from junior high school. Basically, education may influence the paradigm and capability in maintaining and developing their farm. The low education background of the farmers becomes the obstacle for them to accept a certain innovation (Yunasaf et al., 2011).

Based on the farming experience, $56.85 \%$ of goat farmers had low experience in raising livestock ranging from 0-5 years. Raising livestock experience related to the capability of farmer in raising the livestock. The longer experience of raising livestock, the better skill of farmer to maintain their farm. According to Budiraharjo and Setiadi (2004), experience of raising and maintaining livestock may affect the capability of farmer to manage their farm, so that it may also affect the decision making. The low experience in raising goat leads to the difficulties of farmer to implement recording system. Recording system is thought as unnecessary matter and most of the farmers were not interested to apply it.

Based on the number of livestock ownership, $58.59 \%$ respondents have goats from 0.07 to 0.42 AU. The low number of goats will cause less income of the farmers get. According to Budiraharjo and Setiadi (2004) the number of livestock owned is the most important in achieving goal of production. Fewer numbers of goat owned by farmers led to less self-motivated farmers to improve the management of livestock raising through the recording system.

Result of the study showed that no farmer had main livelihood. The raising of goat was just for the side job and for savings as stated by Budiraharjo and Setiadi (2004), in which the goat farming business only the second job and for saving. Generally, most of the respondents worked as farmer, labor, teacher and entrepreneur. Traditional mindset that farmer as the second job created difficulties to accept the innovation of recording system.

\section{Simultaneous Regression Coefficient Test}

Simultaneous regression coefficient test was utilized to observe the effect of $\mathrm{X}$ variables on $\mathrm{Y}$ variable. According to Roflin (2009), the 
simultaneously test was intended to analyze the effect of exogenous variable on endogenous variable. Based on the linear regression analysis, the innovation factor of recording system simultaneously affected the adoption by goat farmers.

\section{Parsial Regression Coefficient Test}

Partial regression coefficient test was used to observe the influence of exogenous variable on endogenous variables partially. It can be seen in Table 1, the internal factor such as age, education background, farming experience, total number of livestock ownership and primary livelihood did not significantly affect adoption. Meanwhile, motivation, innovation characteristics and information source significantly affected the adoption.

\section{Path Analysis}

Path analysis is a development method of multiple linear regression analysis. It was utilized to observe direct and indirect influence of exogenous variables on endogenous variables. It was stated by Sarwono (2007) that path analysis is a method to analyze the causal correlation in multiple regression if the independent variable directly and indirectly affect the dependent variable.

Because the internal factor $X_{1}$ did not significantly affect adoption variable $\mathrm{Y}$ (Table 1), the trimming method was applied to eliminate the internal factor from the path. In this case trimming method was applied by opting out one insignificant variable. Roflin (2009) stated that the trimming method is used to repair a model a path analysis structure by eliminating insignificant independent variable and recalculate it. Independent variables used in this analysis were motivation $\left(\mathrm{X}_{2}\right)$, innovation characteristics $\left(X_{3}\right)$ and information source $\left(X_{4}\right)$, where the dependent variable was adoption (Y). Structure of causal correlation is presented in Figure 2 and the structural equations are presented in equation 7.

Structural equation:

$$
\begin{array}{r}
\mathrm{Y}=\rho_{\mathrm{YX} 2} \mathrm{X}_{2}+\rho_{\mathrm{YX} 3} \mathrm{X}_{3}+\rho_{\mathrm{YX} 4} \mathrm{X}_{4}+0.021= \\
0.181 \mathrm{X}_{2}+0.727 \mathrm{X}_{3}+0.100 \mathrm{X}_{4}+0.021 \ldots .(7)
\end{array}
$$

\section{Path Analysis of Motivation $\left(\mathrm{X}_{2}\right)$ on Adoption} (Y)

The influence of total path analysis can be detected by summing the direct and indirect effect of a variable. Direct and indirect effects of motivation $\left(\mathrm{X}_{2}\right)$ on adoption $(\mathrm{Y})$ were:

- Direct effect of $X_{2}$ on $Y=\left(\rho Y X_{2}\right)^{2}=(0.180)^{2}=$ 0.032 ;

- Indirect effect of $\mathrm{X}_{2}$ on Y through the correlative relationship of $\mathrm{X}_{3}=\rho \mathrm{YX}_{2} \cdot \mathrm{r}_{\mathrm{x} 2 \times 3} \cdot \rho \mathrm{YX}_{3}=0.180$. $0.913 \cdot 0.730=0.121$

- Indirect effect of $\mathrm{X}_{2}$ on Y through the correlative relationship of $\mathrm{X}_{4}=\rho \mathrm{YX}_{2} \cdot \mathrm{r}_{\mathrm{x} 2 \times 4} \cdot \rho \mathrm{YX}_{4}=0.180$. $0.832 .0 .100=0.015$

- $\mathrm{rY}_{\text {total }}=\left(\rho \mathrm{YX}_{i}\right)^{2}+\sum\left(\rho \mathrm{YX}_{i} \cdot \mathrm{r}_{\mathrm{xixj}} \cdot \rho \mathrm{YX}_{j}\right)=$ $0.032+0.121+0.015=0.168$

The total of direct and indirect effect of motivation on adoption was 0.168 or $16.8 \%$. The motivation $\left(\mathrm{X}_{2}\right)$ variable directly affected adoption (Y) in the recording system about 0.032 or $3.2 \%$. Meanwhile, the indirect effect of innovation characteristic and information source was $13.6 \%$. Indirect effect of $\mathrm{X}_{2}$ on $\mathrm{Y}$ through $\mathrm{X}_{3}$ was 0.121 or $1.21 \%$ and indirect effect of $\mathrm{X}_{2}$ on $\mathrm{Y}$ through $\mathrm{X}_{4}$ was 0.015 or $1.5 \%$. The main role of innovation characteristic and information source as the connector variable to increase adoption gave higher effect than direct effect. It means that in application of recording system by increasing the motivation of goat farmers through innovation characteristic and information source may

Table 1. The Affection of Internal Factor, Motivation, Innovation Characteristics and Information Source Variable on Adoption

\begin{tabular}{lcccc}
\hline \multicolumn{1}{c}{ Variables } & Beta & $\mathrm{T}$ & $\mathrm{Sig}$ & Information \\
\hline Internal Factor & 0.007 & 0.454 & 0.650 & Not Significant \\
Motivation & 0.181 & 18.624 & 0.000 & Significant \\
Innovation Characteristics & 0.727 & 5.996 & 0.000 & Significant \\
Information Source & 0.100 & 3.554 & 0.001 & Significant \\
\hline
\end{tabular}




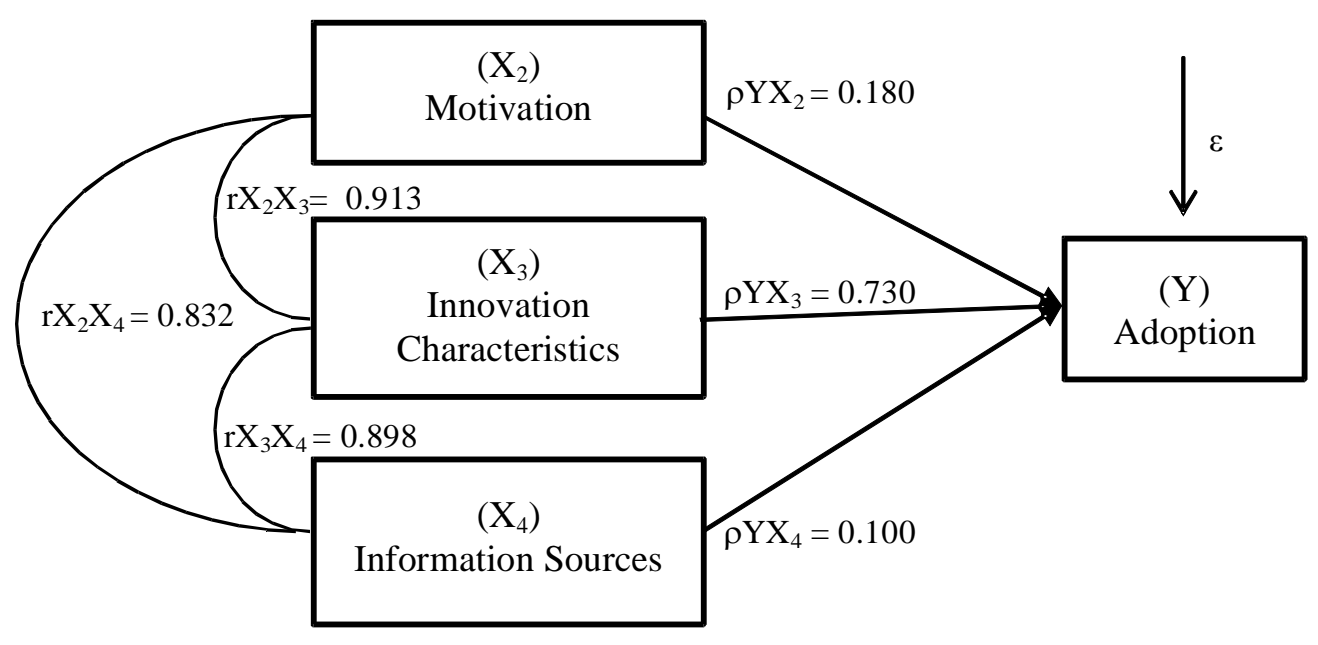

Figure 2. Casual Correlation Structure of $X_{3}, X_{3}$ and $X_{3}$

increase the adoption about $16.8 \%$.

Motivation relates to the self effort of farmers to improve production management. The higher motivation, the faster achievement that farmers have faster adoption will bring benefit. According to Gustisyah (2009), motivated individual is a person that substantially does the effort to handle the main goal of production. Improving motivation of farmers can be done routinely by giving information about recording system through socialization program and improving capability to increase the innovation character. Bulu et al. (2009) stated that farmers whose have more information link will be easier to obtain the new information so they have higher chance to adopt innovation.

The farmers aware in developing business can be done by improving the management. One of the important characteristic of goat farm management was recording system availability. Recording system was used to manage production easier, so it can be evaluated easily. According to Lindstrom (1976), the objective of recording system was to help regular management to make useful data for the farmers. In the location of study, viewer farmer have already implemented recording system, tough it was still simple. Usually, materials used were book and wooden wall. The recorded items were date of birth, disease and livestock ownership data.

\section{Path Analysis of Innovation Characteristic $\left(\mathbf{X}_{3}\right)$ on Adoption (Y)}

The influence of total path analysis can be detected by summing the direct and indirect effect of a variable. A direct and indirect effect of innovation characteristics $\left(\mathrm{X}_{3}\right)$ on adoption $(\mathrm{Y})$ were:

- Direct effect of $\mathrm{X}_{3}$ on $\mathrm{Y}=\left(\rho \mathrm{YX}_{3}\right)^{2}=(0.730)^{2}=$ 0.533

- Indirect effect of $X_{3}$ on $Y$ through the correlative relationship of $\mathrm{X}_{2}=\rho \mathrm{YX}_{3} \cdot \mathrm{r}_{\mathrm{x} 2 \mathrm{x} 3} \cdot \rho \mathrm{YX}_{2}=0.730$ $.0 .913 \cdot 0.180=0.121$

- Indirect effect of $\mathrm{X}_{3}$ on $\mathrm{Y}$ through the correlative relationship of $\mathrm{X}_{4}=\rho \mathrm{YX}_{3} \cdot \mathrm{r}_{\mathrm{x} 3 \mathrm{x} 4} \cdot \rho \mathrm{YX}_{4}=0.730$ $0.898 .0 .100=0.066$

- $\mathrm{rY}_{\text {total }}=\rho \mathrm{YX}_{i}+\sum\left(\rho \mathrm{YX}_{i} \cdot \mathrm{r}_{\mathrm{xixj}} \cdot \rho \mathrm{YX}_{j}\right)=0.533$ $+0.121+0.066=0.720$

The total of direct and indirect affect of innovation characteristics on adoption was 0.720 or $72 \%$. Innovation characteristics $\left(\mathrm{X}_{3}\right)$ variable directly affected on adoption (Y) in the recording system for about 0.533 or $53.3 \%$. Meanwhile, the indirect effect of motivation and information source was 0.187 or $18.7 \%$. Indirect effect of $\mathrm{X}_{3}$ on $\mathrm{Y}$ through $\mathrm{X}_{2}$ was 0.121 or $12.1 \%$ and indirect effect of $\mathrm{X}_{3}$ on $\mathrm{Y}$ through $\mathrm{X}_{4}$ was 0.066 or $6.6 \%$. Innovation characteristics $\left(X_{3}\right)$ variable had the highest effect on adoption (Y). The role of direct influence of innovation characteristic gave higher effect of increasing recording system adoption if compared to indirect influence through motivation and information source. It means that in application of recording system by increasing the innovation characteristic a goat farmer through motivation and information source may increase the adoption for about $72 \%$.

Innovation characteristic was related to 
farmer's perception about recording system. The relationship was observed based on relative advantages, compatibility, complexity, trialability and observability. The easier to be applied, the faster the process of recording system to be accepted. According to Karto (2008), innovation will be easily accepted when farmer see the example of usage, the success and useful.

Innovation characteristic of goat farmer on recording system was low. The farmer still assumed that recording system was difficult to be applied, useless and not profitable. The fear existence of failed and useless of recording system making the respondent did not apply it. Farmers were difficult to adopt innovation because the frequency of extension activity on recording system was conducted just for several time. It was stated by Bulu et al. (2009) that innovation adoption was affected by innovation information consisted of accessing to communication channel, communication frequency and communication intensity of innovation.

\section{Path Analysis of Information Source $\left(\mathrm{X}_{4}\right)$ on Adoption (Y)}

The influence of total path analysis can be detected by summing the direct and indirect effect of a variable. Direct and indirect effects of information source $\left(\mathrm{X}_{4}\right)$ on adoption $(\mathrm{Y})$ were:

- Direct effect of $\mathrm{X}_{4}$ on $\mathrm{Y}=\left(\rho \mathrm{YX}_{4}\right)^{2}=(0.100)^{2}=$ 0.01

- Indirect effect of $\mathrm{X}_{4}$ on $\mathrm{Y}$ through the correlative relationship of $\mathrm{X}_{2}=\rho \mathrm{YX}_{4} \cdot \mathrm{r}_{\mathrm{x} 2 \mathrm{x} 4} \cdot \rho \mathrm{YX}_{2}=0.100$ $0.832 .0 .180=0.015$

- Indirect effect of $\mathrm{X}_{4}$ on $\mathrm{Y}$ through the correlative relationship of $\mathrm{X}_{3}=\rho \mathrm{YX}_{4} \cdot \mathrm{r}_{\mathrm{x} 3 \mathrm{x} 4} \cdot \rho \mathrm{Y} \mathrm{X}_{3}=0.100$ $0.898 .0 .730=0.066$

- $\mathrm{rY}_{\text {total }}=\rho \mathrm{YX}_{i}+\sum\left(\rho \mathrm{YX}_{i} \cdot \mathrm{r}_{\mathrm{x} i \mathrm{x} j} \cdot \rho \mathrm{YX}_{j}\right)=0.01$ $+0.015+0.066=0.091$

The total of direct and indirect effect of information source on adoption was 0.091 or $9.1 \%$. The information source $\left(\mathrm{X}_{4}\right)$ variable directly affected on adoption (Y) in the recording system for about 0.01 or $1 \%$. Meanwhile, the indirect effect of motivation and innovation characteristics source was 0.081 or $8.1 \%$. Indirect effect of $\mathrm{X}_{4}$ on $\mathrm{Y}$ through $\mathrm{X}_{2}$ was 0.015 or $1.5 \%$ and indirect effect of $\mathrm{X}_{4}$ on $\mathrm{Y}$ through $\mathrm{X}_{3}$ was 0.066 or $6.6 \%$. The role of motivation and innovation characteristic had a high effect on escalated adoption. Information source was related to diverse and frequent access of communication channel. The farmers received more knowledge of recording system innovation through the information source. Every frequent and information source escalation which observed through motivation $\left(\mathrm{X}_{2}\right)$ and innovation characteristic $\left(\mathrm{X}_{3}\right)$ will increase $9.1 \%$ the adoption.

Innovation characteristic as mediator variable had a high influence on adoption variable was about 0.066 or $6.6 \%$. Innovation characteristics were engaged to the farmer's perception about relative advantages, compatibility, complexity, trialability and observability (Harinta, 2010). The more information source were obtained both from mass media and interpersonal, the better perception of the farmer. Goat farmer will interest and try to apply recording system, so the complexity of innovation can be reduced. Even, social and economic benefit will eventually come. According to Indraningsih (2011), compatibility and complexity aspect become consideration of decision making whether to adopt the technology or not.

\section{Residual Coefficient Path}

Based on the analysis of direct and indirect effect by using trajectory path analysis model, the total effect of $\mathrm{X}_{2}, \mathrm{X}_{3}$ and $\mathrm{X}_{4}$ on $\mathrm{Y}$ was 0.979 or $97.9 \%$. Coefficient determination was 0.979 . The values of residue coefficient path a presented in equation 8 and 9.

$\rho Y \varepsilon=\sqrt{1-0.979}=0.1449 \ldots \ldots \ldots \ldots \ldots \ldots \ldots(8)$
$\left(\rho Y_{\varepsilon}\right)^{2}=0.1449 \times 0.1449=0.021 \ldots \ldots \ldots \ldots \ldots \ldots . . . \ldots(9)$
The value of $97.9 \%$ indicated that information in the data can be explained by the research variable, whereas $2.1 \%$ was explained by the variable of outside of the model. The effect of innovation factors of recording system affected the adoption by goat farmer about $97.9 \%$ through the motivation variable $\mathrm{X}_{2}$, innovation characteristic $X_{3}$ and innovation source $X_{4}$. Therefore, the structural equation was:

$Y=0.168 X_{2}+0.720 X_{3}+0.091 X_{4}+0.021_{\varepsilon} \ldots$

\section{CONCLUSION}

The total effect of motivation, innovation characteristic and information source variables on adoption variable were $0.168,0.720$ and 0.091 . Innovation characteristic variable gave the highest 
effect on recording system adoption. In order to improve the adoption on recording system of goat farmers, it can be conducted by improving the innovation characteristic through the motivation and information source.

\section{REFERENCES}

Budiraharjo, K and A. Setiadi. 2004. Analisis komparatif pendapatan usaha ternak kambing di Kota Semarang berdasarkan skala pemilikan ternak. J.Indonesian Trop. Anim. Agric. 29(1):44-49.

Bulu, Y. G. S. S. Hariadi. A. S. Herianto and Mudiyono. 2009. Pengaruh modal sosial dan keterdedahan informasi inovasi terhadap tingkat adopsi inovasi jagung di kabupaten Lombok Timur Nusa Tenggara barat. Jurnal Agro Ekonomi. 27(1):1-21

Gustisyah, R. 2009. Analisis faktor-faktor yang mempengaruhi motivasi kerja penyuluh perindustrian pada kantor dinas perindustrian dan perdagangan Kota Medan. Tesis. Universitas Sumatera Utara. Medan.

Harinta, Y.W. 2010. Faktor-faktor yang Mempengaruhi Kecepatan Adopsi Inovasi Pertanian di Kalangan Petani di Kecamatan Gatak Kabupaten Sukoharjo. Tesis. Universitas Sebelas maret. Surakarta

Hendrayani, E and D. Febrina. 2009. Analisis faktor-faktor yang mempengaruhi motivasi beternak sapi di Desa Koto Benai Kecamatan Benai Kabupaten Kuantang Singingi. Jurnal Peternakan 6(2):53-62.
Indraningsih, K. C. 2011. Pengaruh penyuluhan terhadap keputusan petani dalam adopsi inovasi teknologi usahatani terpadu. Jurnal Agro Ekonomi. 29(1):1-24.

Karto. 2008. Analisis faktor-faktor yang Mempengaruhi Adopsi Refrigerator Sea Water Pada Kapal $\geq 20$ GT (Suatu Kasus di PPI Karangsong Kabupaten Indramayu Provinsi Jawa Barat). Tesis. Program Pascasarjana Universitas Diponegoro. Semarang

Kosgey, I. S. S. M. Mbuku. A. M. Okeyo. J. Amimo. J. Philipsson and J. M. Ojango. 2011. Institutional and organizational frameworks for dairy and beef cattle recording in Kenya: a review and opportunities for improvement. Animal Genetic Resources. 48:1-11.

Lindstrom, U. B. 1976. Milk recording in developing countries. World Anim. Rev. 19:34-p42.

Roflin, E. 2009. Penggunaan metode trimming pada analisis jalur dalam menentukan model kausal dana alokasi umum Kabupaten/Kota di Provinsi Sumatera Selatan. Jurnal Penelitian Sains. Edisi Khusus. 09(12-01):19

Sarwono, J. 2007. Analisis Jalur untuk Riset Bisnis dengan SPSS. Andi Offset. Yogyakarta.

Yunasaf, U. A. S. Masdar and S. Alim. 2011. Hubungan keberdayaan peternak sapi perah dengan tingkat keberhasilan usaha ternak. Jurnal Ilmu Ternak. 11(1):27-34 